\title{
Why does the Photobioreactors Fail?
}

Luis G Ramírez-Mérida ${ }^{1,2}$, Leila Queiroz Zepka ${ }^{2}$ and Eduardo Jacob-Lopes ${ }^{2^{*}}$

${ }^{1}$ Applied Biotechnology Center, Department of Biology, University of Carabobo, Universidad Avenue, 2002, Valencia, Edo. Carabobo, Venezuela

${ }^{2}$ Food Science and Technology Department, Federal University of Santa Maria, UFSM, Roraima Avenue 1000, 97105-900, Santa Maria, RS, Brazil

*Corresponding author: Eduardo Jacob-Lopes, Food Science and Technology Department, Federal University of Santa Maria, UFSM, Roraima Avenue 1000, 97105-900, Santa Maria, RS, Brazil, Tel: +55-553-220-8822; E-mail: jacoblopes@pq.cnpq.br

Received date: June 26, 2015, Accepted date: July 06, 2015, Published date: July 10, 2015

Copyright: (c) 2015 Ramirez-Merida LG. This is an open-access article distributed under the terms of the Creative Commons Attribution License, which permits unrestricted use, distribution, and reproduction in any medium, provided the original author and source are credited.

\section{Letter to Editor}

In recent decades, the concern for the development of sustainable processes, maintenance of natural resources, reduction of pollutants, processing of waste products, among others, has generated many investigations that seek to provide viable, effective and productive solutions. Carbon dioxide $\left(\mathrm{CO}_{2}\right)$ emissions have been monitored by its alarming gradual increase in recent years. This pollutant is the main greenhouse gas, and therefore responsible to potential climate changes. International organizations have implemented measures aimed at controlling and reducing emissions of this gas in the atmosphere [1].

Various $\mathrm{CO}_{2}$ sequestration techniques have been developed worldwide. Of these, microalgae-based processes are considered one the most promising. These systems aim to mitigate $\mathrm{CO}_{2}$ emissions from various industrial manufacturing sectors, since that, microalgae cells use $\mathrm{CO}_{2}$ as carbon source for synthesizing value added compounds such as biomass, exopolymers and volatile organic compounds [2].

The development of microalgae cultures requires the use of a reactor vessel, usually called as photobioreactor, who is a bioreactor which incorporates some type of light source, natural or artificial. Two main kinds of photobioreactors are used in large scale: open and closed systems. Closed systems are preferred because provides a greater control of $\mathrm{CO}_{2}$ and lighting, therefore there is better use for $\mathrm{CO}_{2}$ sequestration by microalgae, producing higher yields of bioproducts [3]. The microalgae cells that develop in the closed photobioreactor do not interact with the environment preventing the contamination of the culture and large losses of $\mathrm{CO}_{2}$, which allows better performances in terms of carbon dioxide conversion. The available closed photobioreactor configurations are numerous; however, the most commonly used commercially are the tubular types [4].

Conversely, the industrial conversion of carbon dioxide is very limited by the availability of an ideal photobioreactor. The main bottleneck to be solved in the design of photobioreactors is the configuration, basically represented by the geometric parameters of the systems. Carbon dioxide is a pollutant generated in very high quantities and, consequently, high working volumes are required in a mature industrial process. In laboratory and pilot scale, the conventional configurations meet the basic needs of the processes. In the meantime with the increase in scale, they present operational problems, mainly in the demand for lighting. Therefore, solve industrial demand of photobioreactors to applied in full-scale at field conditions is the main target of this technology.
The main limitations, disadvantages and faults of the conventional photobioreactors are presented for various reasons such as: (i) appropriate availability of light; (ii) $\mathrm{CO}_{2}$ loss during injection; (iii) inadequate mixing and poor mass transfer; (iv) accumulation of photosynthetic oxygen $\left(\mathrm{O}_{2}\right)$, (v) the limitation of the working volumes and (vi) scalability $[5,6]$.

For design of these photobioreactors, it is important to maintain parameters such as the ratio height/diameter column (H/D) between $5-10$, thereby achieving conditions close to the ideal lighting, which severely limits the scale-up [7]. In order to provide an adequate working volume of photobioreactor, the diameter of reactor should be high, that limit the light transfer to the system [8]. So, is imperative the design of new photobioreactors configurations applied industrially and the initial project conditions should be a H/D ratio below of 2.0, not limiting the suitable light supply to the cells.

Finally, to date, none of the photobioreactor meets with the requirements to industrial carbon dioxide sequestration. So taking into consideration geometric parameters as the $\mathrm{H} / \mathrm{D}$ ratio, it could be a fundamental step forward for the consolidation of this technology.

\section{References}

1. Song C (2006) Global challenges and strategies for control, conversion and utilization of $\mathrm{CO} 2$ for sustainable development involving energy, catalysis, adsorption and chemical processing. Catal Today 115: 2-32.

2. Jacob-Lopes E, Zepka LQ, Queiroz MI (2014) Cyanobacteria and carbon sequestration. In: Cyanobacteria: An Economic Perspective. Sharma NK, Rai AK, Stal LJ (eds.), Wiley Blackwell, pp: 65.

3. Pulz O, Scheibenbogen K, Grob W (2001) Biotechnology with cyanobacteria and microalgae. In: Biotechnology Set, Second Edition. Rehm HJ, Reed G, Puhler A, Stadler P (eds.), Wiley-VCH, pp: 107.

4. Gonzalez-Fernandez C, Molinuevo-Salces B, García-González MC (2010) Open and enclosed photobioreactors comparison in terms of organic matter utilization, biomass chemical profile and photosynthetic efficiency. Ecol Eng 36: 1497-1501.

5. Jacob-Lopes E, Revah S, Hernández S, Shirai K, Franco T (2009) Development of operational strategies to remove carbon dioxide in photobioreactors. Chem Eng J 153: 120-126.

6. Molina Grima E, Acién Fernández FG, García Camacho F, Chisti Y (1999) Photobioreactors: light regime, mass transfer, and scale-up. J Biotechnol 70: 231-247.

7. Ramírez-Mérida LG, Zepka LQ, Jacob-Lopes E (2015) Current status, future developments and recent patents on photobioreactor technology. Recent Pat Eng 9: 1-10.

8. Jacob-Lopes E, Franco T (2013) From oil refinery to microalgal biorefinery. Journal of CO2 Utilization 2: 1-7. 